\title{
Inguinal Metastasis from Basal Cell Carcinoma of the Vulva
}

\author{
Anna Katrina Dalton ${ }^{a} \quad K^{\prime}$ Man Wan ${ }^{a} \quad$ Deborah Gomes $^{b}$ \\ Jenny Ma Wyatt ${ }^{\mathrm{b}}$ Martin K. Oehler ${ }^{\mathrm{a}}$ \\ aDepartment of Gynaecology Oncology, Royal Adelaide Hospital, Adelaide, SA, Australia; \\ bepartment of Anatomical Pathology, Royal Adelaide Hospital, Adelaide, SA, Australia
}

\section{Keywords}

Basal cell carcinoma $\cdot$ Vulva $\cdot$ Lymph node metastasis

\begin{abstract}
Vulval basal cell carcinomas (BCC) are an important differential diagnosis of painful, itchy vulval lesions, which can occur at all ages but commonly affect women in their senium. $\mathrm{BCC}$ tend to grow locally in an invasive and destructive pattern and seldom metastasize. Here we describe the rare case of inguinal metastasis in a 70-year-old woman with vulval BCC who was treated with radical hemivulvectomy, bilateral inguinal node sampling and adjuvant external beam radiotherapy. We discuss the clinical management of vulval BCC and provide an overview of the previously reported cases in the literature.

$$
\begin{aligned}
& \text { (c) } 2019 \text { The Author(s) } \\
& \text { Published by S. Karger AG, Basel }
\end{aligned}
$$
\end{abstract}

\section{Introduction}

Basal cell carcinomas (BCC) are a rare vulval skin pathology accounting for only $2-4 \%$ of vulval malignancies [1]. They usually present as a slowly growing ulcer or nodule but due to 


\section{Case Reports in Oncology}

lack of symptoms or the stigma of vulval disease, delayed diagnosis is not uncommon. If untreated, BCC tend to grow locally in an invasive and destructive pattern but have a very low propensity for metastatic spread. Here we present an uncommon case of vulval BCC with metastasis to inguinal lymph nodes and give an overview of previously reported cases in the literature.

\section{Case Presentation}

A 70-year-old woman presented to her general practitioner with a persistent vulval lesion she had first noticed 2 years earlier. She reported occasional vulval discomfort and chronic serous discharge. Her past history included obesity (body mass index of 30), cholecystectomy and tubal ligation. Her only regular medication was vitamin C. Gynaecological examination revealed a large left sided $40 \times 40 \mathrm{~mm}$ ulcerated, nodular lesion with rolled edges. The lesion involved the left labium majus and labium minus (Fig. 1). Punch biopsies were taken under local anaesthetic which showed a nodular and superficial basal cell carcinoma with invasion into the dermis on histopathology. No perineural invasion was identified. Immunohistochemistry for BerEP4, a marker for BCC, was positive.

The patient was subsequently referred to the gynaecological oncology service for management. A staging CT of the abdomen and pelvis was performed showing left labium majus thickening, consistent with a vulval lesion and bilateral mildly enlarged superficial inguinal nodes.

The patient underwent a radical left hemivulvectomy and exploration of both groins. She had a prominent left inguinal lymph node and a mildly enlarged right inguinal lymph node which were both removed. The operation was uncomplicated and the patient discharged after an overnight stay in hospital. The postoperative course was uneventful.

The final histopathology showed an extensively ulcerated $40 \times 40 \mathrm{~mm}$ basal cell carcinoma of the left vulva with nodular, multifocal, superficial, keratotic and infiltrating components. The tumour was invading into the subcutis to a maximal depth of $11.5 \mathrm{~mm}$. Perineural invasion was identified with foci suspicious for lymphovascular invasion. The excision margins were clear by $3 \mathrm{~mm}$ on the 12 and 3 o'clock margins and $4 \mathrm{~mm}$ on the 6 and 9 o'clock margins (Fig. 2,3). The left inguinal node showed tumour deposit of metastatic BCC measuring $10 \mathrm{~mm}$ in diameter with extracapsular extension of $0.7 \mathrm{~mm}$ (Fig. 4). The right inguinal lymph node was negative. A postoperative positron-emission tomography (PET) scan showed no distant metastasis or residual nodal disease. The BCC was therefore staged as FIGO 3C vulval BCC (as per 2009 FIGO staging of vulval carcinoma). The patient received adjuvant external beam radiotherapy to both groins and the vulva. She had a dose of 60 Gray (Gy) to the left vulva and left groin due to increased risk of local and regional recurrence and 48 Gy to the right groin and right vulva. No concurrent chemotherapy was given and the radiotherapy was well tolerated. The patient is now 6 months post-treatment and is recurrence free. 


\section{Case Reports in Oncology}

Case Rep Oncol 2019;12:573-580

DOI: $10.1159 / 000501769$

(C) 2019 The Author(s). Published by S. Karger AG, Base www.karger.com/cro

Dalton et al.: Inguinal Metastasis from Basal Cell Carcinoma of the Vulva

\section{Discussion}

Inguinal nodal metastasis of vulval BCC is exceedingly rare and this is the only 10th reported case in the literature [2]. Patients with vulval BCC generally present with a vulval lesion or non-specific symptoms such as itch, pain, bleeding or scaly plaques. These cancers are frequently diagnosed when they are large and ulcerated as patients often present late [2]. BCC also tend to be misdiagnosed as they are not heavily pigmented and may be mistaken for eczema or psoriasis. Diagnosis is made by biopsy and histopathology.

While most BCC arise from cumulative sun exposure over time, the exact aetiology of vulval BCC is unknown. Risk factors for BCC development include older age, particularly those in the 7th and 8th decade of life, Caucasian ethnicity, history of chronic skin irritation and exposure to ionising radiation $[3,4]$.

Workup for confirmed vulval BCC should include referral to a gynaecological oncologist, clinical staging and consideration of preoperative imaging (either CT or MRI) to define the extent of the local disease and assess for metastasis [5]. However, the role for preoperative imaging in vulval BCC is controversial and due to the rarity of metastatic disease, there are no guidelines. NCCN guidelines for vulval cancer refer only to squamous cell carcinomas and therefore have limited applicability to vulval BCC. NCCN BCC guidelines recommend imaging studies for cases where extensive disease with bone, soft tissue involvement or perineural invasion is suspected [6]. BCC are classified as high risk based on their location and/or size and factors such as poorly defined borders, recurrent disease, immunosuppression, prior irradiation to the affected area and aggressive growth pattern [6]. High risk locations include face, genitalia, hands and feet. Debate exists regarding routine CT imaging for vulval BCC to exclude metastatic disease given the low prevalence of $0.1 \%[7,8]$. However, CT imaging should be considered in patients with significant risk factors for metastasis such as larger BCC with sizes $\geq 40 \mathrm{~mm}$ and/or deep invasion and aggressive histological subtypes such as adenocystic, infiltrative, morphoeic and basosquamous [9]. These aggressive subtypes also tend to recur more frequently [4].

The gold standard of vulval BCC treatment is surgical excision. There is no defined recommended margin for high risk BCC lesions however subclinical extension should be anticipated when selecting surgical margins [6]. As inguinal lymph node metastases are extremely rare and only 10 cases have been reported in the literature, a routine lymphadenectomy is not recommended. However, cases of successful sentinel lymph node sampling to detect nodal metastasis in BCC, particularly basosquamous cell carcinoma, have been published [10]. Further research is required to determine which patients would benefit from this approach, in particular those with lesions measuring $>20 \mathrm{~mm}$ and/or perineural/lymphatic invasion [11].

Ten cases of metastatic vulval BCC to the inguinal lymph nodes have been reported in the literature (Table 1). Eight women were in the 7th or 8th decade of life, one patient was 42 years old (age range 41-87 years) and the age of one patient was not documented. Although the exact anatomical location of the BCC was not documented, the literature review by Renati et al. suggests that the labia majora are the most common site of vulval BCC, as in our patient [2]. Six out of the 10 cases had large vulval BCCs measuring $50 \mathrm{~mm}$ or greater in diameter. All were larger than $40 \mathrm{~mm}$ in diameter. The histology was infiltrating in 4 cases, and 5 out of 10 cases showed adenoid type cells. Eight out of the 10 cases underwent radical vulvectomy with lymph node dissection. One patient received neoadjuvant radiotherapy prior to surgery, 
which successfully facilitated surgical excision of the lesion. Three patients, including ours, received post-operative radiotherapy. One of the 10 women died as a result of her metastatic vulval BCC. Information on follow up and recurrences in the reported cases was limited.

\section{Conclusion}

Vulval BCC, although rare, should always be considered as a differential diagnosis particularly in older women who present with vulval pruritus or a lesion not responding to topical treatments such as steroid ointments. Biopsy is mandatory if diagnosis is uncertain. Patients with large vulval BCC measuring $\geq 40 \mathrm{~mm}$ in diameter and those with aggressive histological subtypes have a higher risk of inguinal lymph node metastasis and should undergo preoperative CT imaging.

\section{Statement of Ethics}

Written informed consent was provided by the patient to publish this case and associated images.

\section{Disclosure of Statement}

No conflicts of interest to declare.

\section{Funding Sources}

No funding was received.

\section{Author Contributions}

Original research paper written by Anna Dalton, King Wan and Martin K. Oehler. Jenny Ma Wyatt and Deborah Gomes assisted with anatomical pathology slide preparation and photographs.

\section{References}

1 Benedet JL, Miller DM, Ehlen TG, Bertrand MA. Basal cell carcinoma of the vulva: clinical features and treatment results in 28 patients. Obstet Gynecol. 1997 Nov;90(5):765-8.

2 Renati S, Henderson C, Aluko A, Burgin S. Basal cell carcinoma of the vulva: a case report and systematic review of the literature. Int J Dermatol. 2018 Dec; Epub ahead of print.

3 de Giorgi V, Salvini C, Massi D, Raspollini MR, Carli P. Vulvar basal cell carcinoma: retrospective study and review of literature. Gynecol Oncol. 2005 Apr;97(1):192-4. 


\section{Case Reports in Oncology}

\begin{tabular}{l|l}
\hline Case Rep Oncol 2019;12:573-580 \\
\hline DOI: 10.1159/000501769 & $\begin{array}{l}\text { (c) 2019 The Author(s). Published by S. Karger AG, Basel } \\
\text { www.karger.com/cro }\end{array}$ \\
\hline
\end{tabular}

Dalton et al.: Inguinal Metastasis from Basal Cell Carcinoma of the Vulva

4 Mulayim N, Foster Silver D, Tolgay Ocal I, Babalola E. Vulvar basal cell carcinoma: two unusual presentations and review of the literature. Gynecol Oncol. 2002 Jun;85(3):532-7.

5 Wui-Jin K, Greer B, Abu-Rustum N, Campos S, Cho K, Chon H, et al. Vulvar Cancer, Version 1, NCCN Clinical Practice Guidelines in Oncology. J Natl Compr Canc Netw. 2017;15(1):92-120.

6 Bichakjian C, Aasi S, Alam M, Andersen J, Blitzblau R, Bordeaux J, et al. Basal Cell Skin Cancer, Version 1, NCCN Clinical Practice Guidelines in Oncology. J Natl Compr Canc Netw. 2019;14(5):574-97.

7 Suarez-Amor 0, Monteagudo B. Letters to the Editor. J Dermatol. 2009;50:297-8.

8 DeAmbrosis K, Nicklin J, Yong-Gee S. Basal cell carcinoma of the vulva: a report of four cases. Australas J Dermatol. 2008 Nov;49(4):213-5.

9 Ozgediz D, Smith EB, Zheng J, Otero J, Tabatabai ZL, Corvera CU. Basal cell carcinoma does metastasize. Dermatol Online J. 2008 Aug;14(8):5.

10 Jankovic I, Kovacevic P, Visnjic M, Jankovic D, Binic I, Jankovic A, et al. Application of Sentinel Lymph Node Biopsy in Cutaneous Basosquamous Carcinoma. Ann Dermatol. 2011 Sep;23 Suppl 1:S123-6.

11 Kakagia DD, Zapandioti P, Trypsiannis G, Grekou AN, Tsoutsos D. Sentinel lymph node metastasis in primary cutaneous basosquamous carcinoma. A cross-sectional study. J Surg Oncol. 2018 Jun;117(8):1752-8.

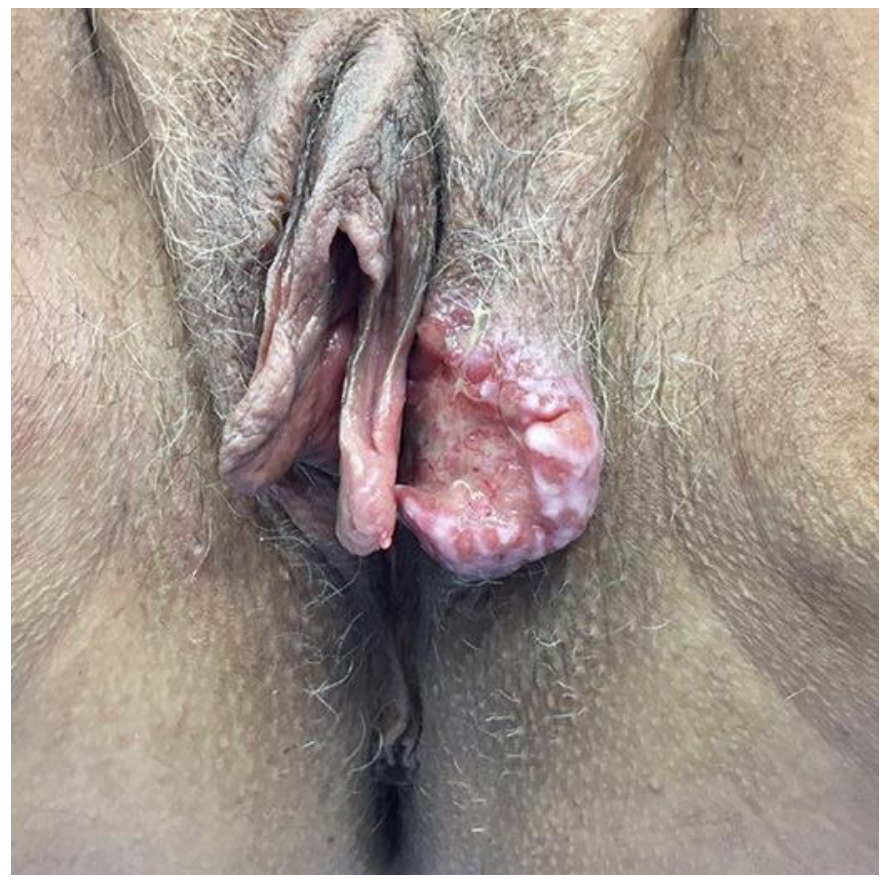

Fig. 1. $40 \times 40 \mathrm{~mm}$ vulval BCC of the left vulva. 


\section{Case Reports in Oncology}

Case Rep Oncol 2019;12:573-580 DOI: $10.1159 / 000501769$ (c) 2019 The Author(s). Published by S. Karger AG, Basel www.karger.com/cro

Dalton et al.: Inguinal Metastasis from Basal Cell Carcinoma of the Vulva

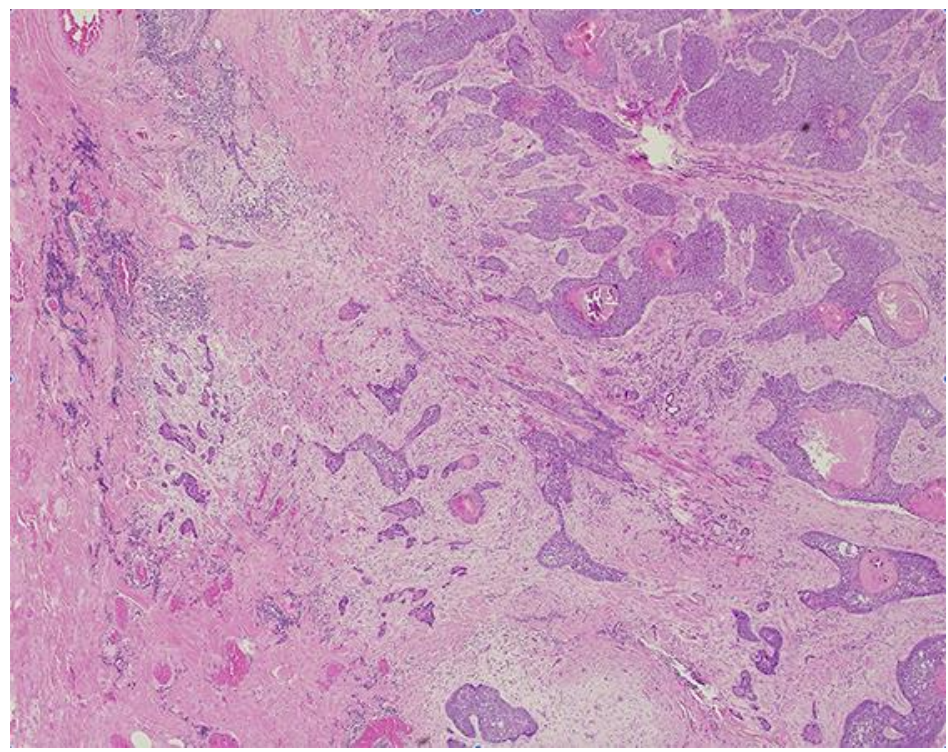

Fig. 2. Vulval BCC, infiltrating component on the left; nodular and keratotic components on the right.

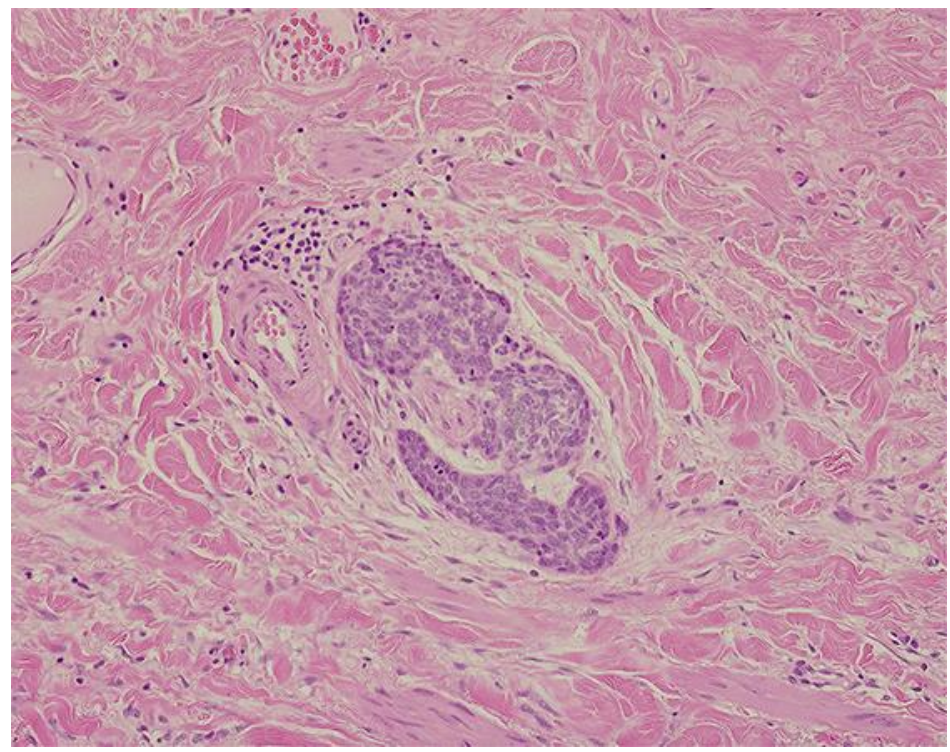

Fig. 3. Vulval BCC with perineural invasion. 


\section{Case Reports in Oncology}

Case Rep Oncol 2019;12:573-580

DOI: $10.1159 / 000501769$

(c) 2019 The Author(s). Published by S. Karger AG, Basel www.karger.com/cro

Dalton et al.: Inguinal Metastasis from Basal Cell Carcinoma of the Vulva

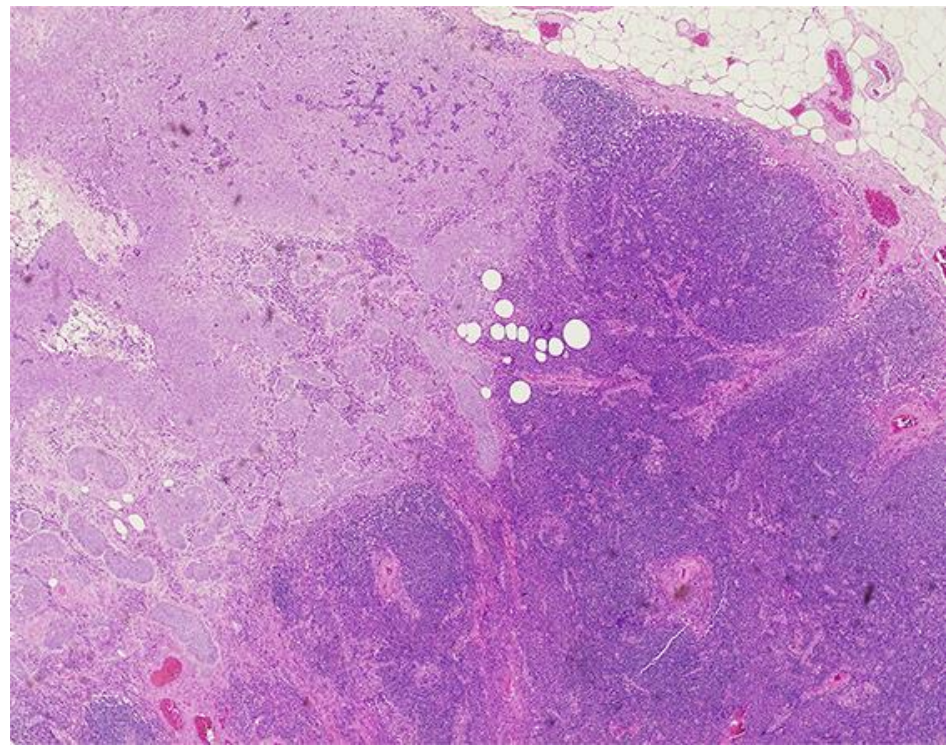

Fig. 4. Inguinal lymph node infiltrated by BCC. 
Table 1. Reported cases of BCC metastasizing to inguinal lymph nodes

\begin{tabular}{|c|c|c|c|c|c|c|}
\hline $\begin{array}{l}\text { Study (primary } \\
\text { author and year) }\end{array}$ & $\begin{array}{l}\text { Patient's } \\
\text { age, years }\end{array}$ & $\begin{array}{l}\text { Dimensions, } \\
\mathrm{mm}\end{array}$ & BCC histology & $\begin{array}{l}\text { Metastasis } \\
\text { location }\end{array}$ & Treatment & Recurrence \\
\hline $\begin{array}{l}\text { Jimenez, } \\
1975\end{array}$ & 41 & $50 \times 50 \times 25$ & $\begin{array}{l}\text { Infiltrative and } \\
\text { squamoid cell }\end{array}$ & $\begin{array}{l}\text { Left inguinal } \\
\text { LN }\end{array}$ & $\begin{array}{l}\text { Radical vulvectomy } \\
\text { bilateral LND }\end{array}$ & - \\
\hline $\begin{array}{l}\text { Sworn, } \\
1979\end{array}$ & 71 & $80 \times 45$ & $\begin{array}{l}\text { Solid and adenoid } \\
\text { pattern }\end{array}$ & $\begin{array}{l}\mathrm{LN} \text { in sub- } \\
\text { cutaneous fat }\end{array}$ & $\begin{array}{l}\text { Radical vulvectomy, bilateral } \\
\text { inguinal lymphadenopathy }\end{array}$ & - \\
\hline $\begin{array}{l}\text { Perrone, } \\
1987\end{array}$ & 86 & $\begin{array}{l}\text { Not provided } \\
\text { - "large" }\end{array}$ & $\begin{array}{l}\text { Adenoid, morphea- } \\
\text { like, keratinizing } \\
\text { pattern }\end{array}$ & $\begin{array}{l}\text { Bilateral } \\
\text { inguinal LN }\end{array}$ & $\begin{array}{l}\text { Radical vulvectomy, bilateral } \\
\text { inguinal LND radiotherapy to } \\
\text { pelvis and groin }\end{array}$ & $\begin{array}{l}\text { No evidence of } \\
\text { recurrence at } 12 \\
\text { months review }\end{array}$ \\
\hline $\begin{array}{l}\text { Hoffman, } \\
1988\end{array}$ & 74 & $\begin{array}{l}60 \times 40 \\
\text { (two lesions) }\end{array}$ & $\begin{array}{l}\text { Adenoid, solid and } \\
\text { keratinizing } \\
\text { pattern }\end{array}$ & $\begin{array}{l}\text { Left inguinal } \\
\text { LN }\end{array}$ & $\begin{array}{l}\text { Radical vulvectomy, bilateral } \\
\text { inguinal LND }\end{array}$ & - \\
\hline $\begin{array}{l}\text { Winkelmann, } \\
1990\end{array}$ & 71 & $60 \times 150$ & $\begin{array}{l}\text { Morphea-like } \\
\text { pattern }\end{array}$ & $\begin{array}{l}\text { Right inguinal } \\
\text { LN }\end{array}$ & $\begin{array}{l}\text { Preoperative radiotherapy to } \\
\text { vulva then radical vulvectomy, } \\
\text { proctectomy, transverse } \\
\text { colostomy and inguinal LND }\end{array}$ & - \\
\hline $\begin{array}{l}\text { Gleeson, } \\
1994\end{array}$ & 86 & $40 \times 25$ & $\begin{array}{l}\text { Nodular, adenoid } \\
\text { pattern }\end{array}$ & $\begin{array}{l}\text { Right inguinal } \\
\text { LN }\end{array}$ & $\begin{array}{l}\text { Radical vulvectomy, bilateral } \\
\text { inguinofemoral LND }\end{array}$ & $\begin{array}{l}\text { No recurrence at } \\
12 \text { months follow-up }\end{array}$ \\
\hline $\begin{array}{l}\text { Mizushima, } \\
1995\end{array}$ & 79 & $100 \times 80$ & $\begin{array}{l}\text { Adenoid, } \\
\text { squamoid pattern }\end{array}$ & $\begin{array}{l}\text { Inguinal LN } \\
\text { and skin on } \\
\text { right thigh }\end{array}$ & $\begin{array}{l}\text { Radical excision of vulval } \\
\text { BCC and bilateral LND then } \\
\text { radiotherapy to right thigh }\end{array}$ & $\begin{array}{l}\text { Skin metastasis to right } \\
\text { thigh } 6 \text { months post } \\
\text { vulval surgery }\end{array}$ \\
\hline $\begin{array}{l}\text { Feakins, } \\
1997\end{array}$ & - & - & $\begin{array}{l}\text { Infiltrative } \\
\text { compact lobular } \\
\text { pattern }\end{array}$ & Inguinal LN & $\begin{array}{l}\text { Radical vulvectomy and } \\
\text { inguinal LND }\end{array}$ & $\begin{array}{l}\text { Local recurrence at } \\
23 \text { months with erosion } \\
\text { into inguinofemoral } \\
\text { blood vessels resulting } \\
\text { in sepsis and death }\end{array}$ \\
\hline $\begin{array}{l}\text { Sakai, } \\
2011\end{array}$ & 87 & $50 \times 37$ & Infiltrative & $\begin{array}{l}\text { Left inguinal } \\
\text { LN }\end{array}$ & Surgical excision & $\begin{array}{l}\text { No evidence recurrence } \\
\text { at } 14 \text { months }\end{array}$ \\
\hline $\begin{array}{l}\text { Dalton, } \\
2019\end{array}$ & 70 & $40 \times 40$ & $\begin{array}{l}\text { Nodular multifocal } \\
\text { superficial, } \\
\text { keratotic and } \\
\text { infiltrating } \\
\text { components }\end{array}$ & $\begin{array}{l}\text { Left inguinal } \\
\text { LN }\end{array}$ & $\begin{array}{l}\text { Radical vulvectomy and } \\
\text { bilateral inguinal LND }\end{array}$ & $\begin{array}{l}\text { No recurrence at } \\
6 \text { months follow-up }\end{array}$ \\
\hline
\end{tabular}

